\title{
RATING TRAINING LOAD OF DISABLED SWIMMERRS IN GENERAL PREPARATION SUB-PERIOD
}

\author{
Bartosz Bolach, 1, A, B Wojciech Seidel, ${ }^{1, B, C, E}$ Mirosław Mrozkowiak 2, C, D \\ ${ }^{1}$ University School of Physical Education in Wrocław, Poland \\ ${ }^{2}$ Physiotherapy Office AKTON, Warsaw, Poland

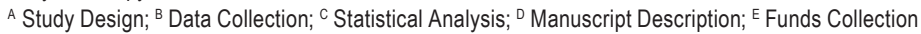 \\ Address for corpespondence: \\ Bartosz Bolach, $\mathrm{PhD}$ \\ University School of Physical Education in Wrocław \\ Al. Ignacego Jana Paderewskiego 35, 51-612 Wrocław, Poland \\ E-mail: bartosz.bolach@awf.wroc.pl
}

\begin{abstract}
Ahstract The aim of the work was to assess the training loads of disabled swimmers in the comprehensive preparation subperiod. The research was carried out on 12 swimmers of the WZSN "START" Wrocław swimming club section. All swimmers started in the "S" start group. The average age of swimmers was 24 years and the average training time was 8 years. The pulse rates were analyzed 6 times during the training, just before the training, in the 10th minute of the warm-up, in the 45th minute at the peak of the training, in the 80th minute, in the 90th minute immediately after the training, and in the 105th minute after the rest. A Polar 810i Sport-tester was used to evaluate the heart rate. Statistical analysis was used. For all the swimmers the average heart rate values after 15 minutes of rest did not return to resting heart rate values. In addition, the swimmer's fatigue was assessed using the Borg scale. The training load was moderate, and on the Borg scale, the swimmers assessed their fatigue as very heavy.
\end{abstract}

Key worlds training loads, swimming by people with disabilities, general preparation sub-period

\section{Introduction}

The level of sport swimming in people with disabilities has increased significantly in recent years. Competitors divided into groups and starter classes are achieving increasingly better sporting results in virtually all swimming competitions (Seidel, Bolach, Kachnikiewicz, Walowska, 2012; Zając, Seidel, 2007).

In the functional classification, three starter groups are distinguished: " $S$ " - freestyle, backstroke and butterfly, "SB" - classic, and "SM" - medley (Uścinowicz, Seidel, Zastawa, Klich, 2013). In the annual training cycle, three periods are distinguished: preparatory, starting, and transitional. According to W. Seidel et al. (2012), the preparatory period is a long training cycle and is divided into three sub-periods:

- general preparation to develop strength, endurance, speed, and swimming technique,

- targeted preparation of increased effort, 
- special preparation of improving swimming technique and speed endurance.

The training load consists of increasing the amount and intensity of swimming across the training sub-ranges. The easiest method of evaluating training intensity is by measuring the heart rate (HR). The training load and selection of training measures are related to many factors such as: age, gender, fitness, and the degree and type of disability. The principle of "super-individualization" is the individual adaptation of the training to these factors, as well as to the predisposition, and the distance the athlete choses. Therefore, the training process for disabled swimmers is much more difficult than with able-bodied people, both in planning and implementation (Costill, 1998; Karpiński, Sachnowski, Oprychał, 2005; Szafraniec, Seidel, Kruszyna, Żurowska, 2012; Zatoń, Jaszak, 2008; Żurowska, Seidel, 2009).

\section{Aim of the study}

The aim of the study was to assess the training loads of disabled swimmers in the general preparation period.

\section{Material and research methods}

12 swimmers from WZSN "Start" Wrocław were studied. The competitors started from four sporting and medical groups:

1. From group I - classes $B 2$ and $B 3$.

2. From group III - classes $A 2, A 3, A 4$ and $A 8$.

3. From the fifth class group - LA5 and LA6.

4. from the sixth class group - CP5, CP7 and CP8.

In terms of functionality, they participated in in classes "S7" to "S13" of the "S" start group. The most numerous groups were amputated and dysfunctional swimmers with lower limb dysfunctions. Six of the swimmers used orthopedic equipment for mobility. The age of the swimmers ranged from 14 to 43 years (average 24 years) and had a swimming experience from 3 to 16 years (average 8 years) (Table 1).

Table 1. Characteristics of the disabled swimmers

\begin{tabular}{cccccc}
\hline Age & Experience (in years) & Education & Sporting medical class & Start class & Type of dysfunction \\
\hline 34 & 11 & Secondary & B2 & S12 & Visually impaired \\
\hline 21 & 6 & Secondary & B3 & S13 & Visually impaired \\
\hline 20 & 13 & Secondary & A2 & S9 & Unilateral thigh amputation \\
\hline 19 & 4 & Secondary & A3 & S8 & Bilateral amputation of the lower leg \\
\hline 14 & 7 & Basic & A4 & S10 & Unilateral amputation of the lower leg \\
\hline 16 & 7 & Basic & A8 & S9 & Dysmelia - hypoplasia of the left upper limb \\
\hline 17 & 9 & Basic & LA5 & S10 & Limiting the range of motion in the hip joint \\
\hline 30 & 3 & Higher & LA5 & S10 & Ankle joint stiffness \\
\hline 29 & 12 & Higher & LA6 & S10 & Total hand failure \\
\hline 19 & 5 & Secondary & CP5 & S7 & Cerebral Palsy \\
\hline 27 & 16 & Higher & CP7 & S7 & Cerebral Palsy \\
\hline 43 & 3 & Higher & CP8 & S8 & Spasticism of both lower limbs following \\
\end{tabular}




\section{Research Method}

The tests were performed in January 2018 during the comprehensive preparation sub-period, in the final 10-day microcycle. Heart rates (HR) were analyzed at 6 moments of the training unit: immediately before training, in the 10-minute warm-up, at the peak of the training (at 45 minutes), in the final part of training (at 80 minutes), immediately after the training (at 90 minutes) and after 15 minutes of rest. A Polar 810i chest mounted heart rate sensor was used to assess heart rate. Additional braces were also used to hold the strap around the chest at high speeds. The level of fatigue was assessed using the Borg scale (no fatigue -1 , maximum fatigue -20 ).

The level of significance in the analysis was $p<0.05$. Calculations were made using the Statistica program. The relationship between the pulse rate and the factors considered was assessed using Student's t-test in independent groups, and the Pearson linear correlation coefficient was determined (Luszniewicz, Słaby, 2001).

\section{Results}

\section{Heart pattes during the general preparation training period}

A noticeable increase in pulse was seen during the first 45 minutes, up to the training peak, after which it progressively decreased. The heart rate variation was not very high (coefficient of variation did not exceed $10 \%$ at each of the tested training moments). After the 15-minute rest, the heart rate gradually slowed toward the initial value, but did not reach it (Table 2).

Table 2. Average heart rates (HR) during the general preparation training units

\begin{tabular}{lrrrr}
\hline \multicolumn{1}{c}{ Pulse } & $\bar{X}$ & SD & Minimum & Maximum \\
\hline Resting & 77.0 & 3.9 & 72 & 84 \\
At 10 min. & 142.3 & 6.8 & 131 & 153 \\
At 45 min. & 200.0 & 10.4 & 182 & 216 \\
At 80 min. & 160.3 & 6.4 & 147 & 171 \\
At 90 min. & 114.8 & 6.5 & 104 & 126 \\
After 15 min. rest & 84.6 & 5.4 & 75 & 91 \\
\hline
\end{tabular}

The fastest changes in average heart rate were found in the first and last 10 minutes of training. The rate of increase between 10 and 45 minutes was faster than the decreases between 45 and 80 minutes (Figure 1).

In the first 10 minutes of warmup exercises, the average heart rate rose by $6.5(142.3-77=65.3)$ beats per minute (bpm). A similar result could be seen in the last 10 minutes, where the value was $4.5 \mathrm{bpm}$. It should be noted that the rate of decline in average heart rate after 15 minutes of training was slower than during 10 minutes of dissolution (Figures 2 and 3). 


\section{0}

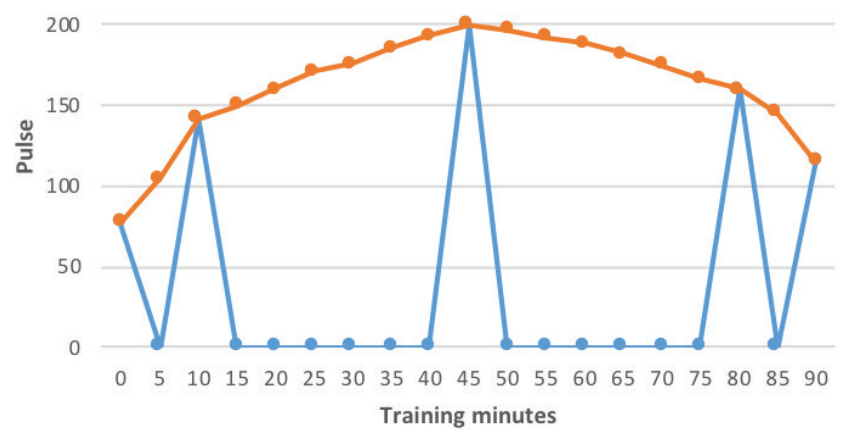

Figure 1. Average heart rates during the general preparation training

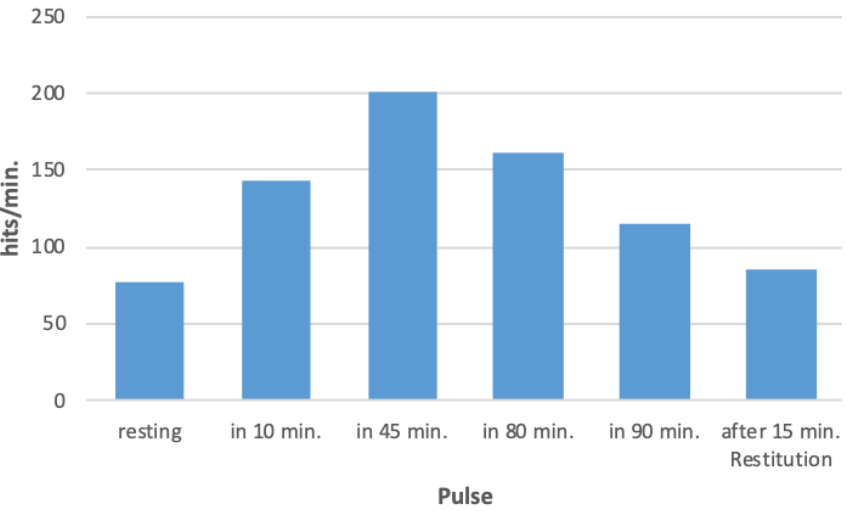

Figule 2. Average heart rates at selected moments of the general preparation training

\section{Heart rate changes [within a minute]}

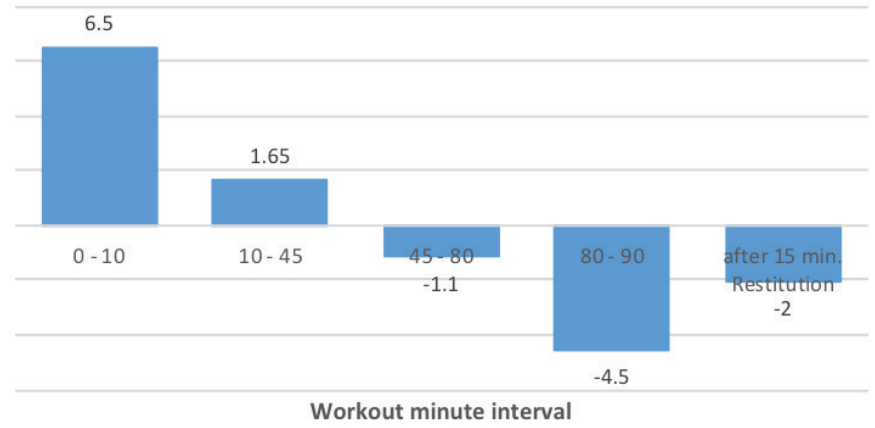

Figure 3. Average rate of pulse change $[H R]$ at selected times of the training units in the tested microcycle (a negative value means a decreasing heart rate) 
After 15 minutes of rest, the average HR value was higher than the average resting heart rate. These differences ranged from 2 to $16 \mathrm{bpm}$. The difference between these measurements was statistically significant (Table 3).

Table 3. Comparison of average resting heart rate (HR) and after 15 minutes rest

\begin{tabular}{|c|c|c|c|c|c|}
\hline \multirow[t]{2}{*}{ Pulse } & \multirow{2}{*}{$\bar{x}$} & \multirow{2}{*}{$S D \pm$} & \multirow{2}{*}{ Average difference } & \multicolumn{2}{|c|}{ Student Test } \\
\hline & & & & $\mathrm{t}$ & $\mathrm{p}$ \\
\hline Resting [T0] & 77.0 & 3.9 & \multirow{2}{*}{+7.6} & \multirow{2}{*}{5.71} & \multirow{2}{*}{0.0001} \\
\hline After $15 \mathrm{~min}$. rest & 84.6 & 5.4 & & & \\
\hline
\end{tabular}

Changes in heart rate after a 15-minute rest were correlated with mean resting heart rate values $(r=-0.5)$. The negative sign of the correlation coefficient was surprising, which means that the swimmers who had a higher peak heart rate after 15 minutes of rest had a similar heart rate value to the resting value than people who had a lower peak heart rate (Table 4).

Table 4. Average peak heart rate values depending on the difference between resting heart rate and after a 15 -minute restitution

\begin{tabular}{ccccc}
\hline Difference between resting heart rate & \multicolumn{2}{c}{ Peak heart rate $(\mathrm{bpmbpm})$} & \multicolumn{2}{c}{ Student Test } \\
\cline { 2 - 3 } and pulse after rest [T0 - Test] & $\overline{\mathrm{X}}$ & std. dev. & $\mathrm{t}$ \\
\hline$<5$ & 205.3 & 8.8 & 1.96 & 0.108 \\
\hline$>10$ & 190.7 & 11.0 & & $\mathrm{~s}$ \\
\hline
\end{tabular}

The rate of change in average heart rate in the first and second half of training had a correlation to the difference between the resting heart rate and the rate after 15 minutes of rest. Both correlations were negative, which shows that the faster the average heart rate increased in each part of the training, the closer the pulse rate after 15 minutes of rest was to the resting pulse rate. The most significant difference was the change in average heart rate from the peak to the final. This correlation was stronger and statistically significant (Table 5).

Table 5. Correlation of average heart rate changes between resting heart rate and after $15 \mathrm{~min}$ rest

\begin{tabular}{ccc}
\hline \multirow{2}{*}{ Changes in heart rate } & \multicolumn{3}{c}{ Correlation with $\left(\mathrm{T}_{0}-\mathrm{T}_{\text {rest }}\right)$} \\
\cline { 2 - 3 } & $\mathrm{r}$ & $\mathrm{p}$ \\
\hline $\mathrm{T}_{\max }-\mathrm{T}_{0}$ & -0.43 & 0.165 \\
$\mathrm{~T}_{\max }-\mathrm{T}_{90}$ & -0.65 & 0.023 \\
\hline
\end{tabular}

\section{Average changes in heart rate and fatigue according to Bory scale}

Disabled swimmers described their fatigue after training as severe, with most of them as very severe (Table 6).

The examined swimmers rated their level of fatigue within 15-19 points of the Borg scale ranking, with an average of 17.25 points and a standard deviation of 1.22 points. The fatigue felt by the swimmers was slightly related 
to the peak pulse value. The Pearson linear correlation coefficient $r=0.13$ and was not statistically significant. However, it was found that clearer correlations of the subjective feeling of fatigue were associated with the pace of changes in the second half of the training, and the difference between the average resting heart rate and after the rest. Correlations had opposite signs, which meant that a greater decrease in heart rate between 45 and 90 minutes of exercise were related to higher fatigue after training (Table 7).

Tahle $\boldsymbol{G}$. Subjective assessment of fatigue of disabled swimmers according to the Borg scale

\begin{tabular}{lccc}
\hline \multirow{2}{*}{ Evaluated effort } & \multirow{2}{*}{ Borg score } & $\mathrm{n}$ & $\%$ \\
\cline { 3 - 4 } & & 3 & 25 \\
Hard & $15-16$ & 7 & 58 \\
Very hard & $17-18$ & 2 & 17 \\
Maximum & $19-20$ & 2 & \\
\hline
\end{tabular}

Tahle 7. Correlations of average heart rate changes with subjectively felt fatigue according to the Borg scale

\begin{tabular}{|c|c|c|}
\hline \multirow{2}{*}{ Changes in heart rate } & \multicolumn{2}{|c|}{ Correlations with fatigue on the Borg scale } \\
\hline & r & $p$ \\
\hline $\mathrm{T}_{\max }-\mathrm{T}_{0}$ & 0.19 & 0.553 \\
\hline$T_{\max }-T_{90}$ & 0.31 & 0.328 \\
\hline $\mathrm{T}_{0}-\mathrm{T}_{\text {rest }}$ & -0.30 & 0.338 \\
\hline
\end{tabular}

\section{Summary}

Training loads depend on many factors, such as the style in which a sportsperson specializes (Jeffrey, Bauerle, 2004; Karpiński et al., 2005; Morouco et al., 2011; Neiva, Fernandes, Vilas-Boas, 2011; Ogonowska, Hubner-Woźniak, Kosmol, Gromisz, 2009; Skórka, Ogiermann, Wilk, 2011). In styles where the lower limbs do more work, more energy is derived from anaerobic sources. Over long distances, energy sources derive from oxygen sources. In training at an intensity of approximately 80\% VO2max, the heart rate should be between 120 and 150 bpm (Kosmol, Hugner-Woźniak, Staniszewski, Słomiński, 2000; Morouco et al., 2011; Neiva et al., 2011; Skórka et al., 2011; Szafraniec et al., 2012). Similar values were obtained for the tested disabled swimmers from "Start" Wrockaw in the initial and final phases of effort. However, with an increase of training load to $90 \%$ VO2max, the heart rate rose to $170 \mathrm{bpm}$. In this case, one could speak of shaping aerobic fitness. The swimmers obtained similar pulse rates at 30 and 70 minutes of training. In contrast, heart rate values at the peak of the training unit indicated a training load of up to $95 \%$ VO2max, which meant that the load is anaerobic lactic acid.

K. Zaton and M. Jaszczak (2008) examined a group of 9 athletes from the Polish Olympic swimming team and found that the intensity of effort of the competitors was within the scope of aerobic training. Anaerobic and mixed effort was much less frequent. According to D.L. Costill (1998), training should oscillate more within the range 120-150 bpm, i.e. medium oxygen intensity training. However, at the time of the main training task, anaerobic loads should prevail. This training pattern is designed to increase the strength of players. 
In conclusion, it should be noted that the load during training is significant, as indicated by the fatigue values given by the competitors on the Borg scale and peak heart rate values, as high as $185 \mathrm{bpm}$. This is also confirmed by the fact that none of the competitors had a pulse rate return to the resting heart rate after the 15-minute rest. Aerobic effort prevailed in the training unit, while at the time of the main task this effort was mixed, and even anaerobic.

\section{Conclusions}

1. The pulse value of any of the swimmers after 15 minutes of rest did not return to the resting value.

2. Disabled swimmers experienced significant training loads in the studied microcycles of the general preparation sub-period.

3. On the Borg scale swimmers rated their fatigue as very severe.

\section{References}

Costill, D.L. (1998). Effects of repeated days of intensified training of muscle glycogen and swimming performance. Medicine and Science in Sports and Exercises, 20, 249-254.

Jeffrey, J., Bauerle, J. (2004). Benefits of balanced training. Swim Tech., 41, 10.

Karpiński, R., Sachnowski, K., Oprychał, C. (2005). Zmiany w szkoleniu pływaków najwyższej klasy. Sport Wyczynowy, 5-6, 25-35.

Kosmol, A., Hugner-Woźniak, E., Staniszewski, T., Słomiński, P. (2000). Kierowanie treningiem pływaków. In: T. Gabryś, A. Kosmol (eds), Wybrane zagadnienia kontroli procesu treningu w sporcie wyczynowym (pp. 124-136). Warszawa: Alma Press.

Luszniewicz, A., Słaby, T. (2001). Statystyka z pakietem komputerowym, Statistica. Warszawa: CH. Beck.

Morouco, P., Neiva, H., Gonzalez-Badillo, J.J., Garido, N., Marincho, D.A., Marques, M.C., Cholewa, J. (2011). Zależności siły i mocy $z$ rezultatami sportowymi w pływaniu. AWF Katowice, 31, 59-70.

Neiva, H.P., Fernandes, R.J., Vilas-Boas, J.P. (2011). Anaerobic critical velocity in Four Swimming Techniques. International Journal of Sport Medicine, 32 (3), 195-198.

Ogonowska, A., Hubner-Woźniak, E., Kosmol, A., Gromisz, W. (2009). Wydolność beztlenowa mięśni kończyn górnych pływaczek i pływaków. Wychowanie Fizyczne i Sport, 53 (4), 193-197.

Seidel, W., Bolach, B. Kachnikiewicz, J., Walowska, J. (2012). Analiza wyników sportowych uzyskanych przez niepełnosprawnych pływaków na Igrzyskach Paraolimpijskich 1992-2008. AWF Wrocław, 39, 84-89.

Skórka, M., Ogiermann, D., Wilk, R. (2011). Zmiany wydolności beztlenowej w rocznym cyklu treningowym pływaków. AWF Katowice, 127-131.

Szafraniec, R., Seidel, W., Kruszyna, D., Żurowska, A. (2012). Aerobic and anaerobic endurance of disabled swimmers in special preparation sub-period. Baltic Journal of health and Physical Activity, 4, 231-237.

Uścinowicz, N., Seidel, W., Zastawa, P., Klich, S. (2013). Metody obiektywizacji i parametryzacji w klasyfikacji funkcjonalnej w pływaniu osób niepełnosprawnych. Fizjoterapia, 21 (3), 50-59.

Zając, A., Seidel, W. (2007). Pływanie osób niepełnosprawnych - wyczyn czy rehabilitacja? Sporty Wodne i Ratownictwo, 1, 156-167.

Zatoń, K., Jaszak, M. (2008). Periodyzacja treningu oraz dobór obciążeń treningowych do imprezy wysokiej rangi w grupie pływaków najwyższej klasy. Science in Swimming II, AWF Wrocław, 114-121.

Żurowska, A., Seidel, W. (2009). Porównanie progresji wyników pełnosprawnych i niepełnosprawnych pływaków w latach 2004-2008. Sporty Wodne i Ratownictwo, 3, 41-48.

Cite this article aS: Bolach, B., Seidel, W., Mrozkowiak, M. (2020). Rating Training Load of Disabled Swimmers in General Preparation Sub-Period. Central European Journal of Sport Sciences and Medicine, 3 (31), 87-93. DOI: 10.18276/cej.2020.3-07. 